\title{
Early School Leaving by Nationality in Contemporary Greece Sociological Interpretations of Recent data
}

\author{
Fotopoulos Nikos \\ Assistant Professor \\ Department of Social \& Education Policy \\ University of Peloponnese \\ Pandis Prokopis \\ Research Associate \\ Center for Educational Policy Development (KANEP-GSEE)
}

\begin{abstract}
Summary
The issue of early school leaving consists one of the most important problems in contemporary educational systems. Although the rate of early school leaving in Greece remains below the European average, it is significant to face this social pathogeny both drastically and decisively. Undoubtedly, the problem of early school leaving is connected with a wider social pathology depicting the deficit of social protection through schools. Additionally, we need to theorize this issue as an urgent problem because of the emerging value that education has as a human and socialright in modern societies. In this paper through the general topic of the early school leaving, we will focus on the specific issue of nationality. Specifically, we will observe the dimension of nationality at primary, low secondary and upper secondary education according to the official data for the pupils' generation 2015-2016. Moreover, using the theoretical and sociological analytical tools, we will examine the issue of early school leaving focusing on the nationality dimension in a period in which, due to the influx of refugees and migrants, the pupils' mobility is increasing rapidly.
\end{abstract}

Keyterms: early school leaving, nationality, educational inequalities, educational and social exclusion

\section{Introduction}

The issue of early school leaving is one of the most urgent issues on the agenda of European education policy(European Commission, 2011).Regardless of the differences either in conceptualizations of the phenomenon or the definitions that are given, it remains one of the most crucial symptoms of modern societies which directly affects boththe essence and quality of modern democracies at global level(Smyth\&Hattam, 2001). Additionally, this phenomenon creates extremely unfavorable conditions for the consolidation of growth and social cohesion in a global scale when the mobility of people, ideas, information, products, labor etc. is proving to be particularly strong and rapidly growing(Ross \&Leathwood, 2013).Arguably, we understand that in the context of a globalized reality education in all its facets and versions has become a key driver of development and modernization of modernsocieties. In this sense, the issue of early school leaving at any level is a direct threat to both the students' personal development and their professional prospects. Additionally, it constitutes a huge threat for the effectiveness and reliability of our educational systems. Therefore, in this paper we will examine the current situation of early school leaving in Modern Greece according to the current statistical data of the Institute of Educational Policy which is the official body for the planning of strategy in field of educational policy in Greece. Under this prism, we will focus on theoretical and sociological interpretations in order to extract the dimension of nationality at primary, low secondary and upper secondary education according to the official data for the pupils' generation 2015-2016. It is beyond any reasonable doubt that the existence and expansion of early school leaving should be theorized as a closely relevant phenomenon to the existing social, economic, and cultural context that shapes the structure and function of the school environment.

\section{Theoretical and Conceptual Framework: rethinking the basic key -factors}

Undoubtedly, one of the key factors influencing the issue of early school leaving is the existence of educational inequalities. Unfortunately, this factor is not related exclusively to the internal school environment but to the wider social, economic and cultural background on which each educational reality is based. This proves that there is a close relationship between education and society through the historical continuum showing that the problem of inequalities is not a new category in the history of understanding of educational systems. On the contrary, it is a diachronic phenomenon, as well as a continuing problem for society as a whole, especially for those countries which theorize education as a basic instrument for the process of democratization. 
In this sense, in the context of modernity, the right to education emerges as a fundamental right, and its protection entails the protection of the democratic society itself(Roth \&Thum, 2010).Elements such as the establishment of public and free of charge education, the universal right to compulsory education, the institutional establishment of equal opportunities in access, the engagement of the educational community in decision-making, the social request for "inclusive education" or" education for all "etc. are undoubtedly parts of the most important and inalienable achievements of modern society.

Briefly, we have to approach the issue of early school leaving through the critical overview of its conceptual framework (Gillies, \& Mifsud, 2016). Hence, every drastic treatment of any social problem requires both the accurate diagnosis and understanding of its anatomy. This means that the essential step before any interventional action is the conceptual framing, as well as the decoding of each type of interpretative schema, definition, theoretical approaches etc. Particularly, it is important to take into our consideration the content of public debate surrounding the conceptual framing of the term, thus taking a holistic and more accurate understanding of what is deemed early school leaving. There is no doubt that there is an important difference when early leaving comes from school education (compulsory) than from lifelong learning structures or initial or continuing educational institutions. This is because each type of education (formal, non-formal, informal, etc.) constitutes a completely different field with specific references, characteristics and particularities shaping its uniqueness within the context of the broader education system. However, even if there are commonalities or horizontal features, it is imperative to approach the "dominant" definitions on the basis of which educational policy is formulated and developed at national, European and international level. It is clear that there are many divergences, ambiguities and overlaps between definitions and conceptual approaches, so that we are faced to clarify the heterogeneous and, in some cases, contradictory conceptual framework. We have to reflect on individual approaches by critically updating and developing the data in order to provide a more complete and more revealing picture of this conceptual field.

According to the European Commission (2014) the lower the level of high school dropout, the fewer people become early school leavers. A first general reference to the term "dropout" is based on the case of those young people who fail to complete their basic (compulsory) education as it is defined by the educational system that is shaped to the standards that a society sets. This is essentially what a society indicates as a minimum guaranteed educational level which obviously applies to all citizens regardless race, social background, sex, nationality, religion etc. In this sense, in a society such as the Greek one, the dropout rate at first concerns those who fail to complete upper secondary education (compulsory secondary education) which, according to the Greek constitution, is defined as the minimum educational, compulsory educational level for every Greek citizen (up to the age of 15).

However, if we take a look at the level of students in upper secondary education (general and vocational) we will observe that the overwhelming majority of adolescents massively attend high school. Nowadays, this means that, despite the formal wording of the law, broader social practices in the field of education appear to have extended the period of studies in the education system creating a higher social expectation of what we call "minimum education" (Lavrijsen, \&Nicaise, 2015).

Hence, it is clear that we must look closely at the qualitative elements (Hodgson, 2007)involved in the analysis and interpretation of the quantitative dimensions highlighting what is necessary for understanding and actively addressing the phenomenon of early school leaving. Consequently, in the extension of the above reasoning, the term "early school leaving" has another meaning as it revolves around all those who fail to complete the education they have begun. In this sense, the term, regardless of the completion of the (minimum) obligation, is considered a much broader term that relates to the non-completion of an obligation, regardless of its level. Thus, we find the term "early school leaving" in other stages than the compulsory one, since it can take place outside the Gymnasium, in the High School, in the University, in the postgraduate, in the lifelong learning structures, in Second Chance Schools and so on and so forth.

In an attempt to classify the key factors (Rodríguez, Vieira, \& Vidal, 2019)on which the phenomenon of early school leaving is based, we could focus on aspects that are related to:

\section{(a) the profile and the individual characteristics of the pupils}

The focus on these factors is based on the individual characteristics of the pupils who are constituted as part of their educational path, their particular profile, the particulars of their individual educational career as well as the individual characteristics that constitute their personality. This broaching aspect is based on a more individual-centered approach, attempting to outline the portfolio each student has acquired, focusing on the knowledge, skills and abilities he or she has acquired, on their performance, learning experiences, either in school or non-formal or informal forms of learning.

\section{(b) the family environment and background}

The focus at this level is built on elements that shape the image of the family environment and relate to elements that determine the socio-economic status of the family, national and cultural origin, performance and educational level of 82 
older family members, family professional and social mobility, the educational expectations of parents, the cultural level of the family environment, the level of social interaction, the relevance of the of the parameters that shape the style and content of social interactions. These elements formulate a background, at times powerful and at times weak, upon which the development of a student's educational profile develops.

\section{(c) the wider social environment}

Factors related to the wider social environment generally relate to the atmosphere in which the family is situated and relate to elements such as its social environment, the educational profile of family friends, their professional status, their financial level their position and prestige within the social pyramid, their position and role in the occupational and social hierarchy, their class origins. In addition, the social environment also concerns other factors related to the wider urban, semi-urban, rural and residential environment which influences the integration of the family within a wider geographical and regional context. These elements undoubtedly contribute to the conscious and sometimes unconscious way in which the educational path of social subjects is determined.

\section{(d) the school environment}

These factors relate to the internal environment of the school and relate to factors such asassessment practices, pedagogical practices, disciplinary and behavioral issues, rules, relationships with teachers and peers. However, it is necessary to note that despite this schematic classification, we could in no way accept the operation of these factors in an unambiguous and static manner. On the contrary, these factors need to be construed within their dialectical unity and, most importantly, "read" through the interpretation of the contradictions and conflicts they have (Ross, \&Leathwood, 2013). It is clear that both interaction and dialectic synthesis are the key to understanding the sequence of motifs. For example, it is more than certain that you cannot isolate subjective factors from a family environment that is broader in a larger social context or that you cannot examine a school environment detached from the broader geographic or regional context.

\section{The role of nationality through the key factors of early school leaving}

According to our topic we have to examine analytically the role of nationality through the rates of early school leaving in contemporary Greece. With no doubts the role of nationality has emerged as a one of the main factorsdue to its importance through the refugee crisis. Even if Greece had been accepting migrant's flows since 90's, after the period of collapse of the Soviet Union, nowadays there is a growing tendency towards refugee flows changing the current situation. Nevertheless, we are not sure about the accurate rate of these flows due to the intensive mobility of people all these years. The certain element due to the complexity of the phenomenon (Koehler, \& Schneider, 2019)is that we have to study carefully all provided data according to the methods and measures of the European standards. Hence, there is no doubt that the problem of early school leaving is not based exclusively to the role of nationality. On the contrary as we highlighted above there are many key factors which play a significant role to the phenomenon of early school leaving. However,we need to see more close this relevant new variable as an independent category mapping all the trends according to the official data. In Greece the basic nationalities which are statistical important are Albanian, Bulgarian, Romanian, Indian.Hence, there is a growing rate of the unknown nationality which accurately expresses both the "complexity" and "darkness" of the situation.

Early school leaving in primary school by nationality

\begin{tabular}{|c|c|c|c|c|c|c|c|c|}
\hline \multicolumn{5}{|l|}{$A^{\prime}-$ B' $^{\prime}$ - C' Grade } & \multicolumn{4}{|c|}{ D'-E'-St' Grade } \\
\hline Nationality & $\begin{array}{l}\text { Regularly } \\
\text { registered }\end{array}$ & $\begin{array}{l}\text { Early } \\
\text { school } \\
\text { leavers }\end{array}$ & $\begin{array}{l}\text { Early } \\
\text { school } \\
\text { leaving } \\
\%\end{array}$ & $\begin{array}{l}\text { \% On the } \\
\text { total of } \\
\text { Early } \\
\text { school } \\
\text { leaving }\end{array}$ & $\begin{array}{l}\text { Regularly } \\
\text { registered }\end{array}$ & $\begin{array}{l}\text { Early } \\
\text { school } \\
\text { leavers }\end{array}$ & $\begin{array}{l}\text { Early } \\
\text { school } \\
\text { leaving } \\
\%\end{array}$ & $\begin{array}{l}\% \text { On the } \\
\text { total of } \\
\text { Early } \\
\text { school } \\
\text { leaving }\end{array}$ \\
\hline Greece & 80.890 & 811 & 1,00 & 47,42 & 87.297 & 847 & 0,97 & 62,97 \\
\hline $\begin{array}{l}\text { Other Countries } \\
\text { within EU }\end{array}$ & 191 & 6 & 3,14 & 0,35 & 198 & 4 & 2,02 & 0,29 \\
\hline $\begin{array}{l}\text { Unknown } \\
\text { Nationality }\end{array}$ & 13.861 & 595 & 4,29 & 34,79 & 3.411 & 253 & 7,41 & 18,4 \\
\hline
\end{tabular}




\begin{tabular}{|c|c|c|c|c|c|c|c|c|}
\hline EU Countries $^{I}$ & 51 & 2 & 3,92 & 0,11 & 34 & 2 & 5,88 & 0,14 \\
\hline Cyprus & 6 & 0 & 0,00 & 0,00 & 9 & 0 & 0,00 & 0,00 \\
\hline Bulgaria & 398 & 52 & 13,06 & 3,04 & 372 & 35 & 9,40 & 2,54 \\
\hline Romania & 340 & 33 & 9,70 & 1,92 & 375 & 22 & 5,86 & 1,6 \\
\hline France & 1 & 1 & 100 & 0,05 & 4 & 0 & 0,00 & 0,00 \\
\hline Germany & 7 & 1 & 14,28 & 0,05 & 11 & 1 & 9,09 & 0,07 \\
\hline Italy & 6 & 0 & 0,00 & 0,00 & 7 & 0 & 0,00 & 0,00 \\
\hline Poland & 81 & 5 & 6,17 & 0,29 & 66 & 2 & 3,03 & 0,14 \\
\hline Great Britain & 10 & 1 & 10,00 & 0,05 & 20 & 4 & 20,00 & 0,29 \\
\hline Albania & 6.786 & 118 & 1,73 & 6,90 & 7.031 & 131 & 1,86 & 9,96 \\
\hline Belarus & 1 & 0 & 0,00 & 0,00 & 2 & 0 & 0,00 & 0,00 \\
\hline Moldavia & 66 & 2 & 3,03 & 0,11 & 74 & 2 & 2,70 & 0,14 \\
\hline Ukraine & 63 & 2 & 3,17 & 0,11 & 64 & 3 & 4,68 & 0,21 \\
\hline Russia & 29 & 2 & 6,89 & 0,11 & 29 & 3 & 10,34 & 0,21 \\
\hline Turkey & 8 & 0 & 0,00 & 0,00 & 4 & 0 & 0,00 & 0,00 \\
\hline $\begin{array}{l}\text { FORMER } \\
\text { YUGOSLAVIA } \\
\text { COUNTRIES } \\
\text { OUTSIDE THE EU }\end{array}$ & 25 & 1 & 4,00 & 0,05 & 28 & 0 & 0,00 & 0,00 \\
\hline $\begin{array}{l}\text { OTHERS (except } \\
\text { USA, Canada) }\end{array}$ & 7 & 1 & 14,28 & 0,05 & 8 & 0 & 0,00 & 0,00 \\
\hline USA, Canada & 5 & 0 & 0,00 & 0,00 & 3 & 0 & 0,00 & 0,00 \\
\hline Asia others & 16 & 2 & 12,50 & 0,11 & 10 & 1 & 10,00 & 0,07 \\
\hline Afghanistan & 12 & 11 & 91,66 & 0,64 & 14 & 10 & 71,42 & 0,72 \\
\hline India & 102 & 5 & 4,90 & 0,29 & 131 & 4 & 3,05 & 0,29 \\
\hline Iraq & 10 & 2 & 20,00 & 0,11 & 7 & 2 & 28,57 & 0,14 \\
\hline Iran & 2 & 0 & 0,00 & 0,00 & 2 & 0 & 0,00 & 0,00 \\
\hline China & 35 & 5 & 14,28 & 0,29 & 23 & 2 & 8,69 & 0,14 \\
\hline Lebanon & 3 & 0 & 0,00 & 0,00 & 1 & 0 & 0,00 & 0,00 \\
\hline Bangladesh & 38 & 7 & 18,42 & 0,40 & 32 & 4 & 12,5 & 0,29 \\
\hline Pakistan & 63 & 3 & 4,76 & 0,17 & 85 & 5 & 5,88 & 0,36 \\
\hline Syria & 70 & 10 & 14,28 & 0,58 & 66 & 20 & 30,30 & 1,45 \\
\hline Philippines & 62 & 3 & 2,06 & 0,17 & 70 & 2 & 2,85 & 0,14 \\
\hline Africa other & 33 & 10 & 30,30 & 0,58 & 32 & 7 & 21,87 & 0,50 \\
\hline Egypt & 84 & 8 & 9,52 & 0,46 & 83 & 6 & 7,22 & 0,43 \\
\hline Ethiopia & 13 & 6 & 46,15 & 0,35 & 10 & 2 & 20,00 & 0,14 \\
\hline Morocco & 10 & 0 & 0,00 & 0,00 & 5 & 0 & 0,00 & 0,00 \\
\hline Nigeria & 35 & 2 & 5,71 & 0,11 & 23 & 1 & 4,34 & 0,07 \\
\hline OCEANIA ALL & 9 & 3 & 33,33 & 0,17 & 7 & 0 & 0,00 & 0,00 \\
\hline Total & 103.429 & 1.710 & 1,65 & 100 & 99.648 & 1.375 & 1,37 & 100 \\
\hline
\end{tabular}

Nationality is a relatively new variable for early school leaving and its examination is particularly important in the context of the worsening socio-economic and refugee crisis. In the Table 1 above we can see the dropout by nationality, including Greek, for both primary education cohorts. The two (2) major population nationalities present in the Greek public primary education is Greek and Albanian. In the first cohort (A'-C' Grade) the Greek nationality represents the $47,42 \%$ of the total early school leaving but the actual rate is only $1,00 \%$ as only 811 Greek students, from the 80,970 regularly registered, have abandoned school in this first cohort. In the second cohort (D' - St' Grade) the relative numbers for the Greek nationality are $62,97 \%$ of the total, while $0,97 \%$ is the actual early school leaving rate as 847 Greek students have abandoned school in the second cohort of the primary education.

\footnotetext{
${ }^{1}$ Austria, Belgium, Denmark, Switzerland, Estonia, Ireland, Iceland, Italy, Netherlands, Croatia, Latvia, Lithuania, Liechtenstein, Luxembourg, Malta, Norway, Hungary, Portugal, Slovakia, Slovenia, Sweden, Czech Republic, Finland plus the following Countries: WING COUNTRY: Iceland, Liechtenstein and Norway 
The second most populous nationality is the "unknown" due to several reasons previously analyzed representing $34,79 \%$ of the total early school leaving in the first cohort and 18,4\% in the second cohort. Respectively the early school leavingrates per cohort are $4.29 \%$ and $7.41 \%$. The Albanian nationality comes next as it represents $6,90 \%$ of the total early school leaving in the first cohort of primary education and the $9,96 \%$ in the second cohort. The actual rate of the Albanian nationality students is only $1,73 \%$ in the first cohort, as 118 Albanian students have left school in this cohort from a total of 6.786 and 1,86\% in the second cohort as 131 Albanian nationality students have left school in this cohort from a total of 7.031. The Albanian nationality students seems to be fully adapted in the Greek education system and in Greek society in general as their performance, in terms of early school leaving, is great and very close to Greek nationality students.

Other nationalities worth mentioning are Bulgarian, Romanian and Indian, as they all have a significant number of regularly registered students in both cohorts with at least 100 regularly registered students in each one. The early school leaving rate for the Bulgarian students is really significant as it reaches 13,06\% for the first cohort and 9,40\% for the second cohort. Similar is the situation for the Romanian students. In the first cohort the early school leavingrate is 9,70\% and it is reduced to 5,86\% in the second cohort. Regarding the Indianstudents, we could tell that the situation is far better given the fact that only 5 students $(4,90 \%)$ have left school in the first cohort and only 4 students $(3,05 \%)$ in the second cohort.

Finally, we need to stress our focus in the Afghan students. Almost any student from the regularly registered has abandoned school in the first cohort (11 out of 12,91,66\%) and the situation remains almost the same in the second cohort $(10$ out of $14,71,42 \%)$.In the chart 1 below, we can see the six larger, by school population, nationalities and their early school leavingrates in each cohort of the Greek primary education.

\section{Chart 1: The early school leaving in primary school by Nationality}

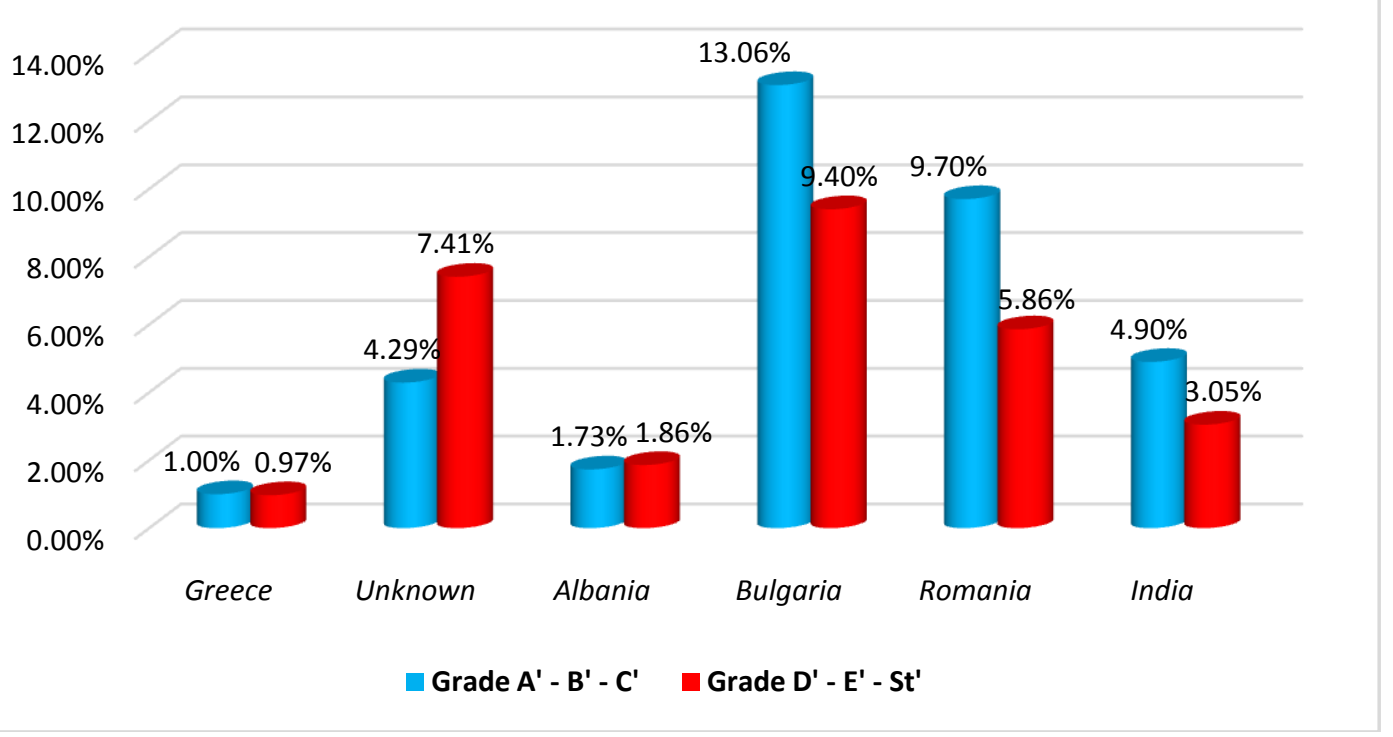

Source: Institute of Education Policy (2019)

The early school leaving in low-secondary education (Gymnasio) by nationality

Table 2: Early school leaving in low-secondary education by Nationality (Generation of students: 2015-16)

\begin{tabular}{|l|l|l|l|l|}
\hline Nationality & $\begin{array}{l}\text { Regularly } \\
\text { registered }\end{array}$ & $\begin{array}{l}\text { Early school } \\
\text { leavers }\end{array}$ & $\begin{array}{l}\text { Early school } \\
\text { leaving } \\
\text { \% }\end{array}$ & $\begin{array}{l}\text { \% On the total } \\
\text { of Early } \\
\text { school leavers }\end{array}$ \\
\hline Greece & 87.918 & 2.488 & 2,83 & 51,89 \\
\hline $\begin{array}{l}\text { Other Countries } \\
\text { within EU }\end{array}$ & 210 & 20 & 9,52 & 0,41 \\
\hline $\begin{array}{l}\text { Unknown } \\
\text { Nationality }\end{array}$ & 3.151 & 1.409 & 44,72 & 29,39 \\
\hline
\end{tabular}




\begin{tabular}{|c|c|c|c|c|}
\hline EU Countries $^{2}$ & 29 & 3 & 10,34 & 0,06 \\
\hline Cyprus & 10 & 1 & 10,00 & 0,02 \\
\hline Bulgaria & 609 & 135 & 22,17 & 2,81 \\
\hline Romania & 465 & 46 & 9,89 & 0,95 \\
\hline France & 4 & 0 & 0,00 & 0,00 \\
\hline Germany & 15 & 1 & 6,67 & 0,02 \\
\hline Italy & 5 & 1 & 20,00 & 0,02 \\
\hline Poland & 102 & 12 & 11,76 & 0,25 \\
\hline Great Britain & 34 & 5 & 14,71 & 0,10 \\
\hline Albania & 7.644 & 488 & 6,38 & 10,17 \\
\hline Belarus & 5 & 1 & 20,00 & 0,02 \\
\hline Moldavia & 78 & 4 & 5,13 & 0,08 \\
\hline Ukraine & 67 & 5 & 7,46 & 0,10 \\
\hline Russia & 59 & 4 & 6,78 & 0,08 \\
\hline Turkey & 11 & 2 & 18,18 & 0,04 \\
\hline $\begin{array}{l}\text { FORMER } \\
\text { YUGOSLAVIA } \\
\text { COUNTRIES } \\
\text { OUTSIDE THE } \\
\text { EU }\end{array}$ & 24 & 0 & 0,00 & 0,00 \\
\hline $\begin{array}{l}\text { OTHERS (except } \\
\text { USA, Canada) }\end{array}$ & 15 & 2 & 13,33 & 0,04 \\
\hline USA, Canada & 10 & 1 & 10,00 & 0,02 \\
\hline Asia others & 34 & 4 & 11,76 & 0,08 \\
\hline Afghanistan & 48 & 39 & 81,25 & 0,81 \\
\hline India & 119 & 5 & 4,20 & 0,10 \\
\hline Iraq & 14 & 10 & 71,43 & 0,20 \\
\hline Iran & 8 & 6 & 75,00 & 0,12 \\
\hline Israel & 1 & 0 & 0,00 & 0,00 \\
\hline China & 13 & 5 & 38,46 & 0,10 \\
\hline Lebanon & 2 & 1 & 50,00 & 0,02 \\
\hline Bangladesh & 26 & 8 & 30,77 & 0,16 \\
\hline Pakistan & 67 & 17 & 25,73 & 0,35 \\
\hline Syria & 101 & 47 & 46,53 & 0,98 \\
\hline Philippines & 67 & 3 & 4,48 & 0,06 \\
\hline Africa other & 41 & 7 & 17,07 & 0,14 \\
\hline Egypt & 75 & 10 & 13,33 & 0,20 \\
\hline Ethiopia & 6 & 0 & 0,00 & 0,00 \\
\hline Morocco & 6 & 1 & 16,67 & 0,02 \\
\hline Nigeria & 27 & 2 & 7,41 & 0,04 \\
\hline OCEANIA ALL & 4 & 1 & 25,00 & 0,02 \\
\hline Total & 101.124 & 4.794 & 4,74 & 100 \\
\hline
\end{tabular}

Source: Institute of Education Policy (2019)

In the low-secondary education the situation regarding the early school leaving by nationality, remains pretty much the same as in the primary education. Greek and Albanian nationalities are the most populated, excluding the Unknown nationality, and both have very small early school leaving rates, $2,83 \%$ and $6,83 \%$ respectively.

\footnotetext{
${ }^{2}$ Austria, Belgium, Denmark, Switzerland, Estonia, Ireland, Iceland, Italy, Netherlands, Croatia, Latvia, Lithuania, Liechtenstein, Luxembourg, Malta, Norway, Hungary, Portugal, Slovakia, Slovenia, Sweden, Czech Republic, Finland plus the following Countries: WING COUNTRY: Iceland, Liechtenstein and Norway
} 
Due to their very big population they reflect the vast majority $(62,06 \%)$ of the total early school leaving in low secondary education. The "unknown" nationality shows up again a very high rate of early school leaving $(44,72 \%)$ as 1.409 students seems to have abandoned school from a total of 3.151. Other nationalities with remarkable representation (over 100 regularly registered students) in low-secondary Greek education are Bulgarian, Romanian, Indian and Syrian. Starting from the Bulgarian students, according to Table 2, 135 students have abandoned school from a total of 609 , that means the early school leaving rate is $22,17 \%$, which is definitely a very high rate. The situation seems better with the Romanian students, where the rate is 9,89\%, which is still high but much lower than Bulgarian students. Regarding the Polish students, according to Table 2, almost 1 out of 10 students $(11,76 \%)$ are leaving low-secondary education. The situation is far better in the case of Indian nationality students as only 4,20\% are leaving school in low-secondary education. The huge problem is located in the Syrian students where almost 1 out of 2 students $(46,53 \%)$ are leaving school in low-secondary education. As in primary education, it seems that students from Arabic language countries are finding great difficulties on adjusting to the Greek educational system and remaining on it. This is something must be taken under great consideration by the policy makers. In the Chart 2 that follows we can see the 8 most populated nationalities of the Greek low-secondary education and how they perform in terms of early school leaving rates.

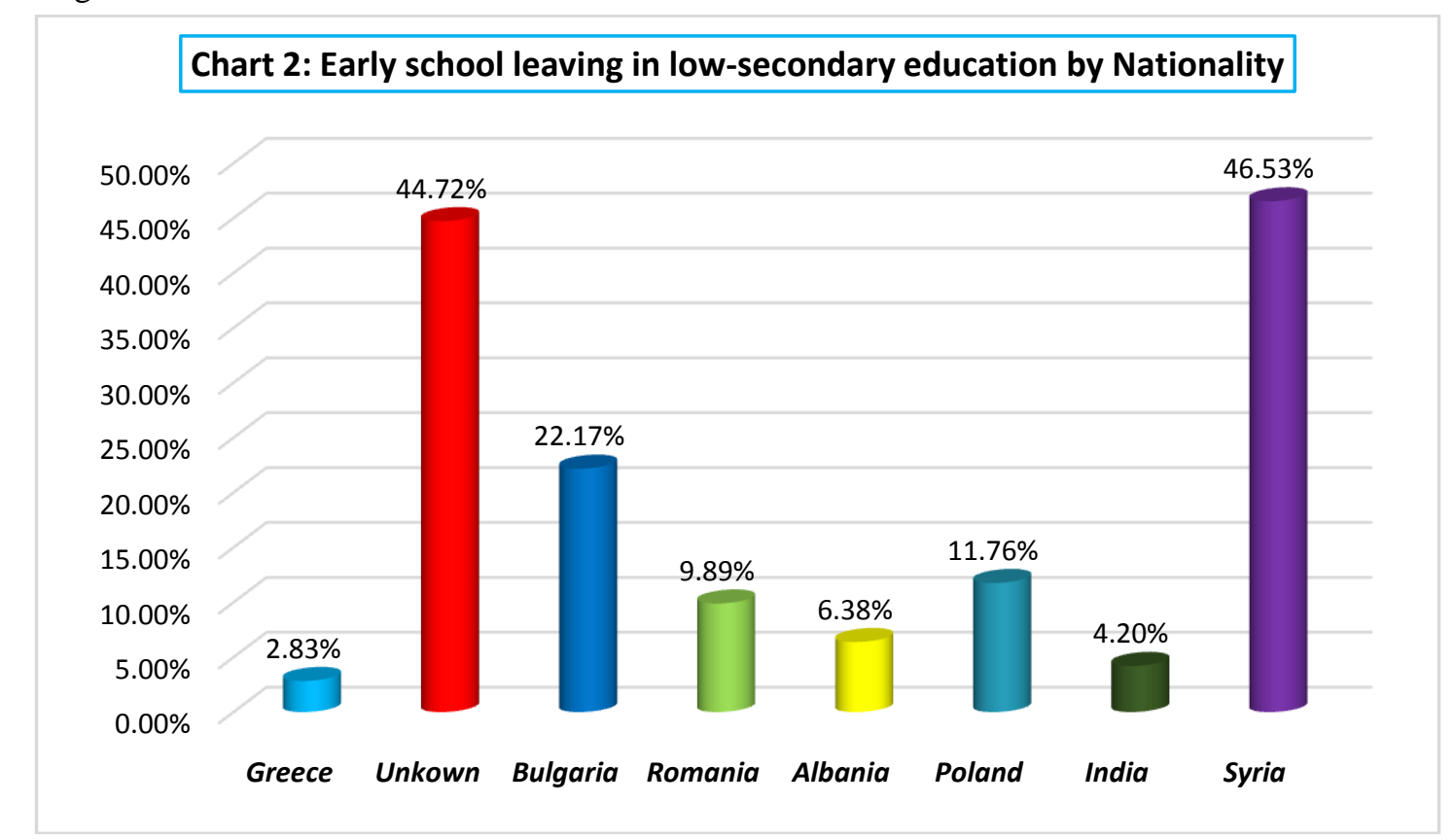

Source: Institute of Education Policy (2019)

The early school leaving in upper-secondary education (Lykeio) by nationality

\begin{tabular}{|l|l|l|l|l|}
\hline \multicolumn{5}{|l|}{$\begin{array}{l}\text { Table 3: Early school leaving in upper-secondary education by Nationality } \\
\text { (Generation of students: 2015-16) }\end{array}$} \\
\hline Nationality & $\begin{array}{l}\text { Regularly } \\
\text { registered }\end{array}$ & $\begin{array}{l}\text { Early school } \\
\text { leavers }\end{array}$ & $\begin{array}{l}\text { Early school } \\
\text { leaving } \\
\text { \% }\end{array}$ & $\begin{array}{l}\text { \% On the } \\
\text { total of Early } \\
\text { school leavers }\end{array}$ \\
\hline Greece & 73.380 & 675 & 0,92 & 54,39 \\
\hline $\begin{array}{l}\text { Other Countries } \\
\text { within EU }\end{array}$ & 113 & 9 & 7,96 & 0,72 \\
\hline $\begin{array}{l}\text { Unknown } \\
\text { Nationality }\end{array}$ & 1.191 & 326 & 27,37 & 26,26 \\
\hline EU Countries & 25 & 2 & 8,00 & 0,16 \\
\hline
\end{tabular}

\footnotetext{
${ }^{3}$ Austria, Belgium, Denmark, Switzerland, Estonia, Ireland, Iceland, Italy, Netherlands, Croatia, Latvia, Lithuania, Liechtenstein, Luxembourg, Malta, Norway, Hungary, Portugal, Slovakia, Slovenia, Sweden, Czech Republic, Finland plus the following Countries: WING COUNTRY: Iceland, Liechtenstein and Norway
} 


\begin{tabular}{|c|c|c|c|c|}
\hline Cyprus & 8 & 0 & 0,00 & 0,00 \\
\hline Bulgaria & 144 & 13 & 9,03 & 1,04 \\
\hline Romania & 211 & 11 & 5,21 & 0,88 \\
\hline France & 2 & 1 & 50,00 & 0,08 \\
\hline Germany & 16 & 2 & 12,50 & 0,16 \\
\hline Italy & 5 & 0 & 0,00 & 0,00 \\
\hline Poland & 75 & 6 & 8,00 & 0,48 \\
\hline Great Britain & 16 & 1 & 6,25 & 0,08 \\
\hline Albania & 3.538 & 152 & 4,30 & 12,25 \\
\hline Belarus & 2 & 0 & 0,00 & 0,00 \\
\hline Moldavia & 53 & 2 & 3,77 & 0,16 \\
\hline Ukraine & 47 & 6 & 12,77 & 0,48 \\
\hline Russia & 39 & 2 & 5,13 & 0,16 \\
\hline Turkey & 6 & 0 & 0,00 & 0,00 \\
\hline $\begin{array}{l}\text { FORMER } \\
\text { YUGOSLAVIA } \\
\text { COUNTRIES } \\
\text { OUTSIDE THE EU }\end{array}$ & 19 & 2 & 10,53 & 0,16 \\
\hline $\begin{array}{l}\text { OTHERS (except } \\
\text { USA, Canada) }\end{array}$ & 7 & 0 & 0,00 & 0,00 \\
\hline USA, Canada & 4 & 1 & 25,00 & 0,08 \\
\hline Asia others & 19 & 1 & 5,26 & 0,08 \\
\hline Afghanistan & 8 & 4 & 50,00 & 0,32 \\
\hline India & 27 & 1 & 3,70 & 0,08 \\
\hline Iraq & 3 & 2 & 66,67 & 0,16 \\
\hline Iran & 4 & 3 & 75,00 & 0,24 \\
\hline Israel & 4 & 0 & 0,00 & 0,00 \\
\hline China & 14 & 1 & 7,14 & 0,08 \\
\hline Lebanon & 3 & 0 & 0,00 & 0,00 \\
\hline Bangladesh & 1 & 0 & 0,00 & 0,00 \\
\hline Pakistan & 19 & 5 & 26,32 & 0,40 \\
\hline Syria & 13 & 3 & 23,08 & 0,24 \\
\hline Philippines & 49 & 1 & 2,04 & 0,08 \\
\hline Africa other & 19 & 3 & 15,79 & 0,24 \\
\hline Egypt & 35 & 4 & 11,43 & 0,32 \\
\hline Ethiopia & 3 & 2 & 66,67 & 0,16 \\
\hline Morocco & 4 & 0 & 0,00 & 0,00 \\
\hline Nigeria & 17 & 0 & 0,00 & 0,00 \\
\hline OCEANIA ALL & 1 & 0 & 0,00 & 0,00 \\
\hline Total & 79.144 & 1.241 & 1,57 & 100 \\
\hline
\end{tabular}

In upper-secondary education the situation is not particularly differentiated from low-secondary education. Greece, Albania and "unknown" nationality are once again the most populated nationalities. What differs is the fact that apart from the aforementioned nationalities only Bulgaria and Romania have at least 100 students regularly registered on upper-secondary education. This seems to be rationale as the students from third countries are preferring to continue their studies in vocational education and not in general education which is definitely more difficult to foreign students.

Regarding the early school leaving rates, according to Table 3, Greek students are leaving school in a very small rate $(0,92 \%)$ which practically means that anyone decides to continue in general education mainly graduates from it. The problem with the "unknown" nationality remains in upper-secondary education as in primary and in low-secondary education. The early school leaving rate is very high $(27,37 \%)$ as 326 students are leaving upper-secondary education. As far as Albanian students are concerned, once again theearly school leaving rates are rather small (4.30\%) as only 152 out of 3.538 students have left school in upper-secondary education. 
The Bulgarian students are leaving school in a rate of $9,03 \%$ which is not negligible while the Romania nationality students have a better performance. Specifically, the early school leaving rate is 5,21\% as only 11 students out of 211 have left school in upper-secondary education. In the chart 3 we can see the 5 most populated nationalities in the Greek upper-secondary education and their performance in terms of early school leaving rates.

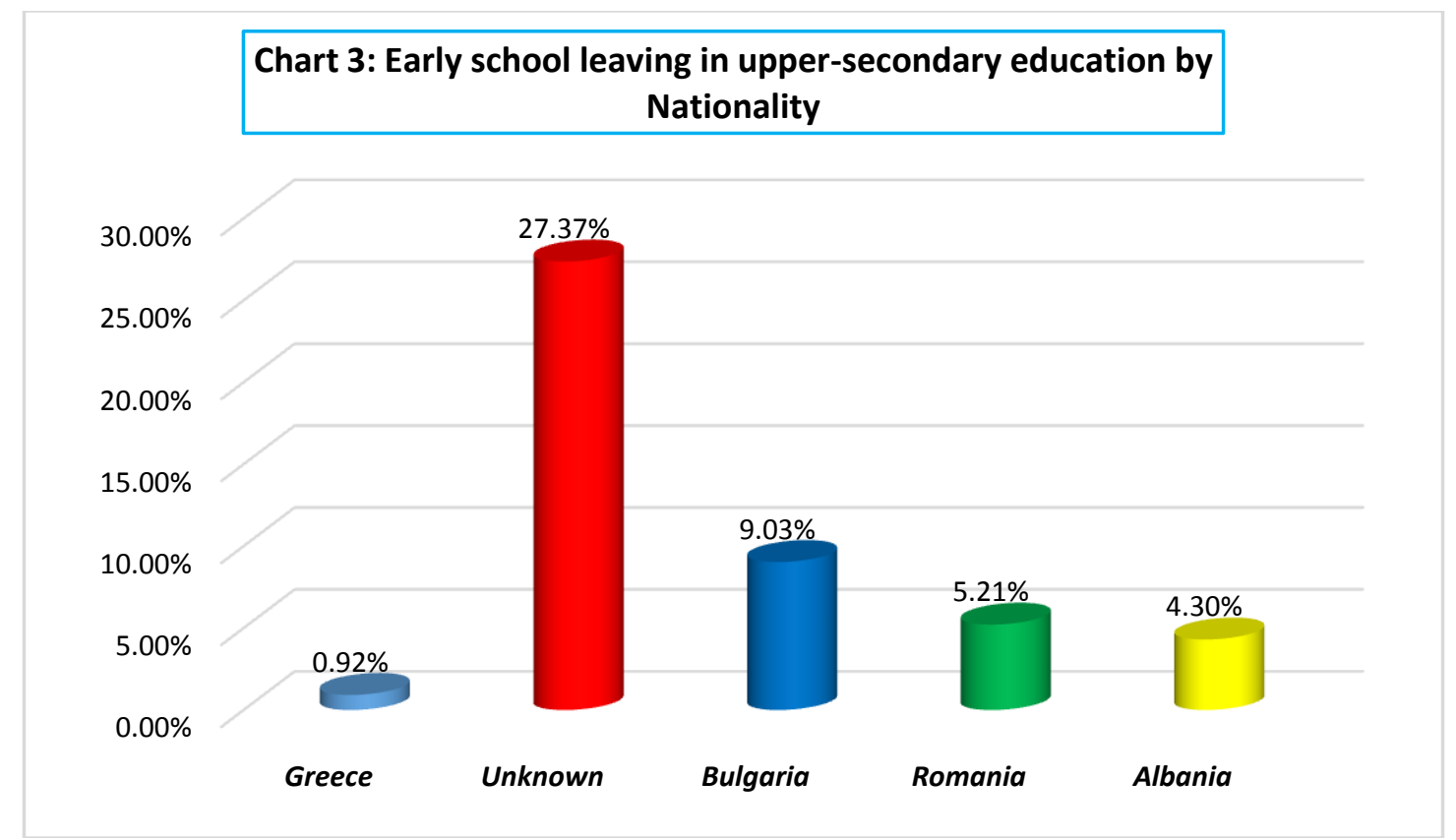

Source: Institute of Education Policy (2019)

\section{Conclusions}

In conclusion, we need to approach the issue of early school leaving both dialectically and compromisingly using all the factors and dimensions that play a significant role into the social function. It is certain that we have to theorize this issue using the understanding of contradictions, as well as internal features in the field of social educational policy. In this sense, we understand that factors such as educational and social inequalities, social background, cultural capital, play a significant role in order to explain the phenomenon of early school leaving. There is no doubt that students who are more susceptible to demonstrating early school leaving behavior present a common cluster of characteristics. Specifically, elements such as psycho-emotional particularities, mental difficulties, emotional, sexual, etc. abuse, parental neglect, domestic violence cases, family instability etc., can constitute an extremely difficult context in which a child tries to remainbalancedor to be actively educated. (Lamote, Speybroeck, Van Den Noortgate, \& Van Damme, 2013). It is understood that, especially in times of crisis, the impact of these factors is further aggravated for students coming from "socially vulnerable groups".

According to our data we see that the role of nationality has emerged as a one of the main dimensions, especially during the refugee crisis. Concluding, in the Greek public primary education the two (2) major population nationalities are the Greek and Albanian ones while the second most populous nationality is the "unknown" due to several reasons previously analyzed. The Albanian nationality comes next as it represents 6,90\% of the total Early school leaving in the first cohort of primary education and the $9,96 \%$ in the second cohort respectively. Other nationalities worth mentioning are the Bulgarian, Romanian and Indian, as they all have a significant number of regularly registered students in both cohorts. In the low-secondary education the early school leaving rate by nationality, remains pretty much the same as in the primary education. Greek and Albanian nationalities are the most populated, excluding the Unknown nationality, and both have very small dropout rates, 2,83\% and 6,83\% respectively. Due to their high amount of population they reflect the vast majority of the total early school leaving in low secondary education. The "unknown" nationality shows up again a very high rate of early school leaving rate. Other nationalities with remarkable appearance are the Bulgarian, Romanian, Indian and Syrian.

However, the early school leaving from compulsory education (primary and secondary) is an extremely brutal 'choice' for a pupil, due to basic education aims to acquire solid knowledge, skills and competences aimed at integrating new members into our social system. It is clear that the loss of this opportunity is a form of violent coercion resulting in the deprivation of a basic human right, whose absence constitutes a direct attack on the effort of emancipation and selffulfillment. 
Undoubtedly, early school leaving especially for migrants and refugees' children is a particularly negative phenomenon related to profound socio-social inequalities, structural inequalities as well as wider geographic and other cultural and religious differences (Chirtes, 2010). With no doubt the existence of the phenomenon of early school leaving poses a direct threat to the substance and quality of democratic politics, thereby reinforcing the vicious circle created by poverty, illiteracy, educational and social exclusion, underdevelopment and social economic stagnation.

\section{References}

Chirtes, G. (2010). A Case Study into the Causes of School Dropout. ActaDidacticaNapocensia, 3(4), 25-34.

European Commission (2011). Tackling early school leaving: A key contribution to the Europe 2020 agenda. Brussels: European Commission.

European Commission/EACEA/Eurydice/CEDEFOP (2014). Tackling Early Leaving from Education and Training in Europe: Strategies, Policies and Measures. Eurydice and CEDEFOP Report. Luxembourg: Publications Office of the European Union.

Hodgson, D. (2007). Towards a more telling way of understanding early school leaving. Issues in Educational Research, 17(1), 40.

Gillies, D., \&Mifsud, D. (2016). Policy in transition: the emergence of tackling early school leaving (ESL) as EU policy priority. Journal of Education Policy, 31(6), 819-832.

González-Rodríguez, D., Vieira, M. J., \& Vidal, J. (2019). Factors that influence early school leaving: a comprehensive model. Educational Research, 61(2), 214-230.

Lamote, C., Speybroeck, S., Van Den Noortgate, W., \& Van Damme, J. (2013). Different pathways towards dropout: the role of engagement in early school leaving. Oxford Review of Education, 39(6), 739-760.

Lavrijsen, J., \&Nicaise, I. (2015). Social inequalities in early school leaving: The role of educational institutions and the socioeconomic context. European Education, 47(4), 295-310.

Koehler, C., \& Schneider, J. (2019). Young refugees in education: the particular challenges of school systems in Europe. Comparative Migration Studies, 7(1), 28.

Institute of Education Policy (IEP) (2019). School dropout in Greek Primary and Secondary Education. Reference period: 2015-2018. Athens: Office of Educational Research and Evaluation, IEP.

Ross, A., \&Leathwood, C. (2013). Problematising early school leaving. European Journal of education, 48(3), 405418.

Roth, F., \&Thum, A. E. (2010). The key role of education in the Europe 2020 strategy. CEPS Working Document, (338).

Smyth, J., \&Hattam, R. (2001). 'Voiced'research as a sociology for understanding'dropping out'of school. British Journal of Sociology of Education, 22(3), 401-415. 